\title{
PENGARUH KEMANDIRIAN PRIBADI, BUDAYA ORGANISASI DAN PENGAWASAN TERHADAP DISIPLIN KERJA PEGAWAI BADAN PENGELOLA KEUANGAN DAN ASET DAERAH
}

\author{
${ }^{1}$ Nuryanti, ${ }^{2}$ Ramadhan Syahputra, ${ }^{3}$ Muhammad Ihsan Hrp, ${ }^{4}$ Radhiah, ${ }^{5}$ Elviana Sinaga \\ $1,2,3,4,5$ Universitas Islam Sumatera Utara \\ Inuryanti@gmail.com, ${ }^{2}$ ramdhan.syahputra@gmail.com, ${ }^{3}$ mhd.ihsan@gmail.com, ${ }^{4}$ radhiah@gmail.com, \\ ${ }^{5}$ elviana.sinaga@gmail.com
}

\begin{abstract}
The problem of this research is: Do independence, organizational culture, and monitoring an effect on employee work discipline. This study aims to determine the effect of independence, organizational culture, and supervision on employee work discipline. With the Total Sampling technique, the sample in this study was 65 people. Personal independence partially has a positive effect on employee work discipline; Organizational culture partially has a positive effect on employee work discipline; Supervision partially has a positive effect on employee work discipline; Personal independence, organizational culture and supervision simultaneously have a positive and significant effect on employee work discipline.
\end{abstract}

Keywords : Personal Independence, Organizational Culture; Supervision; Work Discipline

ABSTRAK : Rumusan masalah dalam penelitian ini adalah : Apakah kemandirian, budaya organisasi, dan pengawasan berpengaruh terhadap disiplin kerja pegawai. Penelitian ini bertujuan untuk mengetahui pengaruh kemandirian, budaya organisasi, dan pengawasan terhadap disiplin kerja pegawai. Dengan teknik Total Sampling maka sampel dalam penelitian ini sebanyak 65 orang. Kemandirian pribadi secara parsial berpengaruh positif terhadap disiplin kerja pegawai; Budaya organisasi secara parsial berpengaruh positif terhadap disiplin kerja pegawai; Pengawasan secara parsial berpengaruh positif terhadap disiplin kerja pegawai; Kemandirian pribadi, budaya organisasi dan pengawasan secara simultan berpengaruh positif dan signifikan terhadap disiplin kerja pegawai.

Kata Kunci : Kemandirian Pribadi, Budaya Organisasi; Pengawasan; Disiplin Kerja

\section{Pendahuluan}

Salah satu persoalan yang muncul berkaitan dengan pegawai sebagai aparatur pemerintah dalam menghadapi tuntutan organisasi yang mengharapkan pegawainya memberikan performa terbaik terhadap pelayanan masyarakat adalah disiplin kerja. Kedisiplinan pada dasarnya merupakan suatu hal mutlak yang harus dijalankan setiap organisasi, karena tanpa adanya dukungan disiplin kerja yang baik, sulit organisasi untuk mewujudkan tujuannya. Disiplin kerja merupakan pelaksanaan manajemen untuk memperteguh pedoman-pedoman. Dalam PP No 53 tahun 2010 tentang Peraturan Disiplin Pegawai Negeri Sipil pada Pasal 1 di jelaskan bahwa : “ Disiplin Pegawai Negeri Sipil adalah kesanggupan Pegawai Negeri Sipil untuk menaati kewajiban dan menghindari larangan yang di tentukan dalam peraturan perundang- undangan dan/atau peraturan kedinasan yang apabila tidak ditaati atau dilanggar dijatuhi hukuman disiplin ". Pelanggaran disiplin adalah setiap ucapan, tulisan atau perbuatan PNS yang tidak menaati kewajiban dan/atau melanggar larangan ketentuan disiplin PNS, baik yang dilakukan di dalam maupun di luar jam kerja (PP No. 53 tahun 2010).

Menurut Wirawan (2010 : 81) disiplin adalah sikap dan perilaku kepatuhan terhadap organisasi, prosedur kerja, kode etik, dan norma budaya organisasi lainnya dalam memproduksi suatu produk dan melayani konsumen organisasi. Dalam hal menjaga keberhasilan dan kelangsungan hidup suatu organisasi maka seorang atasan akan selalu mencoba untuk menjaga dan meningkatkan sumber daya yang dimilikinya termasuk di dalamnya meningkatkan disiplin kerja pegawai (Endriawan, 2014 : 23). 
Menurut Siagian (2015 : 92), terdapat dua kegiatan pendisiplinan dalam organisasi, yaitu :

1) Disiplin Preventif; tindakan yang mendorong para karyawan untuk taat kepada berbagai ketentuan yang berlaku dan memenuhi standar yang ditetapkan. Artinya melalui kejelasan dan penjelasan tentang pola sikap, tindakan dan perilaku yang diinginkan dari setiap anggota organisasi diusahakan pencegahan jangan sampai para karyawan berperilaku negatif. Keberhasilan penerapan pendisiplinan preventif terletak pada disiplin pribadi para anggota organisasi.

2) Disiplin Korektif; tindakan pendisiplinan yang dilakukan setelah pegawai dengan nyata melakukan pelanggaran atas ketentuan-ketentuan yang berlaku atau gagal memenuhi standar yang telah ditetapkan, kepadanya dikenakan sanksi disipliner. Berat atau ringannya suatu sanksi tentunya tergantung pada bobot pelanggaran yang telah terjadi.

Pegawai akan memahami bahwa aktifitasnya merupakan sarana untuk mendapatkan materi serta sebuah bentuk eksistensi dari dalam kehidupnya. Keyakinan tentang kinerja yang tinggi dan rutinitas yang dijalankan akan mendorong pegawai untuk turut serta memberikan masukan-masukan dan ide-ide ke tempat kerja. Sesuai dengan pendapat Sudirman (2015: 35) menyatakan bahwa kemandirian adalah "Perilaku mampu berinisiatif, mampu mengatasi hambatan atau masalah, mempunyai rasa percaya diri dan dapat melakukan sesuatu tanpa bantuan orang lain". Pegawai yang memiliki kinerja positif dengan gerak produktif tidak akan berdiam diri untuk tidak menanggapi lingkungan kerja yang membutuhkan gerak nyata, bukan retorika belaka. Keaktifan pegawai akan membuktikan seberapa jauh inisiatifnya, untuk menuntaskan pekerjaan- pekerjaanya tanpa dikomando oleh atasan.

Pegawai yang tidak bisa bekerja secara tim juga merupakan permasalahan pekerja, dimana pegawai yang individualis justru akan menghambat tercapainya kinerja yang maksimal. Pegawai yang individualis tidak bisa menempatkan diri menjadi pegawai yang memiliki kemandirian. Masalah kemandirian bisa dilihat pada pegawai yang selalu mengekor pada rekan kerjanya, artinya pegawai tersebut tidak bisa mengambil keputusan dalam bersikap. Fenomena tersebut masih banyak dijumpai dalam dunia kerja, hal semacam ini akan sangat mengganggu kinerja team work. Tingkat kemandirian dan kedisiplinan pegawai sangat mempengaruhi produktivitas kerja pegawai dalam rangka mewujudkan tujuan instansi.

Disiplin kerja erat kaitannya dengan pengawasan pimpinan. Pengawasan merupakan tindakan nyata dan paling efektif dalam mewujudkan kedisiplinan pegawai instansi (Hasibuan, 2011 : 84). Hal ini telah dibuktikan oleh beberapa penelitian, salah satunya penelitian yang dilakukan oleh Afrizal Pasaribu (2011) bahwa pengawasan secara parsial mempengaruhi disiplin kerja. Berdasarkan hasil penelitian Tety Asmiarsih M (2016), pengawasan berpengaruh positif terhadap disiplin kerja pegawai Kantor Badan Kepegawaian Daerah Kabupaten Brebes. Berdasarkan nilai Adjusted R Square sebesar 0,649 maka besar pengaruh pengawasan terhadap disiplin kerja sebesar 0,649 dan 0,351 disiplin kerja dipengaruhi oleh faktor lain selain pengawasan. Diketahui bahwa pengawasan adalah faktor dominan yang berpengaruh terhadap displin kerja pegawai.

Menurut Kadarisman (2012 : 99), pengawasan sebagai salah satu fungsi manajemen merupakan suatu proses yang tidak terputus untuk menjaga agar pelaksanaan tugas, fungsi, dan wewenang tidak menyimpang dari aturan yang telah ditetapkan dalam rangka mencapai tujuan organisasi.

Faktor lain yang dapat mempengaruhi disiplin kerja pegawai adalah budaya organisasi yang ada di dalamnya. Berdasarkan hasil penelitian Ni Putu Ester Suniastuti dan I Wayan Suana (2011), yaitu budaya organisasi secara simultan memiliki pengaruh yang signifikan terhadap disiplin kerja pegawai. Budaya organisasi merupakan variabel yang memberikan pengaruh dominan terhadap disiplin kerja.

Menurut Wibowo (2011 : 92), budaya organisasi adalah filosofi dasar organisasi yang memuat kekayaan, norma-norma, dan nilai-nilai bersama yang menjadi karakteristik inti tentang bagaimana cara melakukan sesuatu dalam organisasi. Keyakinan, norma-norma, dan nilai-nilai tersebut menjadi pegangan semua sumber daya manusia dalam organisasi dalam melaksanakan pekerjaannya. Tujuan paling utama dalam suatu organisasi adalah budaya disiplin. Penerapan budaya yang disiplin akan membuat seluruh yang terlibat 
dalam organisasi mampu berjalan sesuai dengan aturan yang sudah ditentukan. Karena budaya organisasi merupakan variabel yang memberikan pengaruh dominan terhadap disiplin kerja (Suniastuti dan Suana, 2011) .

Fenomena yang terjadi terkait dengan kemandirian, budaya organisasi dan pengawasan yang ada di Badan Pengelola Keuangan Dan Aset Daerah Kabupaten Batu Bara yang diindikasikan mempengaruhi disiplin kerja pegawainya. Instansi sudah berupaya melakukan tindakan preventif guna untuk meningkatkan disiplin dalam bekerja pegawai melalui menerapkan program "Budaya Malu" di kantor, serta memasang banner "Budaya Malu" di beberapa sudut kantor guna untuk mengingatkan pegawai agar memiliki kesadaran disiplin kerja yang baik. Namun harapan instansi tidak sesuai dengan fenomena yang ada dilapangan, karena budaya yang diharapkan tidak dapat mengalahkan budaya-budaya yang sudah melekat diantara pegawai-pegawai Badan Pengelola Keuangan Dan Aset Daerah Kabupaten Batu Bara. Sehingga adanya indikasi bahwa faktor kemandirian, budaya organisasi dan pengawasan memiliki pengaruh terhadap disiplin kerja pegawai di Badan Pengelola Keuangan Dan Aset Daerah Kabupaten Batu Bara.

\subsection{Batasan Masalah}

Agar permasalahan yang dikaji terarah maka permasalahan dibatasi sebagai berikut. Penelitian ini hanya membahas tentang pengaruh kemandirian pribadi, budaya organisasi dan disiplin kerja.

\subsection{Rumusan Masalah}

Bedasarkan latar belakang masalah tersebut diatas, maka yang menjadi rumusan masalah dalam penelitian ini adalah :

1) Apakah kemandirian pribadi berpengaruh terhadap disiplin kerja pegawai Badan Pengelola Keuangan Dan Aset Daerah Kabupaten Batu Bara

2) Apakah budaya organisasi berpengaruh terhadap disiplin kerja pegawai Badan Pengelola Keuangan Dan Aset Daerah Kabupaten Batu Bara

3) Apakah pengawasan berpengaruh terhadap disiplin kerja pegawai Badan Pengelola Keuangan Dan Aset Daerah Kabupaten Batu Bara
4) Apakah kemandirian, budaya organisasi, dan pengawasan berpengaruh terhadap disiplin kerja pegawai Badan Pengelola Keuangan Dan Aset Daerah Kabupaten Batu Bara

\subsection{Tujuan Penelitian}

Tujuan penelitian ini adalah :

1) Untuk menganalisis pengaruh kemandirian pribadi terhadap disiplin kerja pegawai Badan Pengelola Keuangan Dan Aset Daerah Kabupaten Batu Bara

2) Untuk menganalisis pengaruh budaya organisasi terhadap disiplin kerja pegawai

Badan Pengelola Keuangan Dan Aset Daerah Kabupaten Batu Bara

3) Untuk menganalisis pengaruh pengawasan terhadap disiplin kerja pegawai Badan Pengelola Keuangan Dan Aset Daerah Kabupaten Batu Bara

4) Untuk menganalisi pengaruh kemandirian, budaya organisasi, dan pengawasan terhadap disiplin kerja pegawai Badan Pengelola Keuangan Dan Aset Daerah Kabupaten Batu Bara.

\subsection{Hipotesis}

Berdasarkan kajian teori dan kerangka pemikiran diatas, maka dapat dirumuskan hipotesis penelitian sebagai berikut :

1) Kemandirian pribadi berpengaruh terhadap disiplin kerja pegawai Badan Pengelola Keuangan Dan Aset Daerah Kabupaten Batu Bara

2) Budaya organisasi berpengaruh terhadap disiplin kerja pegawai Badan Pengelola Keuangan Dan Aset Daerah Kabupaten Batu Bara

3) Pengawasan berpengaruh terhadap disiplin kerja pegawai Badan Pengelolan Keuangan Dan Aset Daerah Kabupaten Batu Bara

4) Kemandirian, budaya organisasi dan pengawasan berpengaruh terhadap disiplin kerja pegawai Badan Pengelola Keuangan Dan Aset Daerah Kabupaten Batu Bara.

\section{Metode Penelitian}

\subsection{Populasi}

Dalam suatu penelitian, populasi yang dipilih mempunyai hubungan yang erat dengan masalah yang diteliti. Populasi atau unverse adalah jumlah keseluruhan unit analisis yang ciricirinya akan diduga, Singarimbun \& Effendi (2012 : 126). Dalam penelitian ini yang menjadi populasi adalah seluruh pegawai Badan 
Pengelola Keuangan Dan Aset Daerah Sehingga tidak dijadikan populasi dan dapat Kabupaten Batu Bara yang berjumlah 66 orang dijelaskan dengan kerangka populasi sebagai kerena Kepala Badan Posisinya masih Plt. berikut:

Tabel 1

Kerangka Populasi Berdasarkan Jabatan Thn. 2021

\begin{tabular}{|c|c|c|}
\hline No & Jabatan & Jlh Populasi \\
\hline 1 & Sekretaris & 1 \\
\hline 2 & Ka. Bidang & 4 \\
\hline 3 & Ka. Sub Bag & 3 \\
\hline 4 & Ka. Sub Bid & 9 \\
\hline 5 & Penata & 1 \\
\hline 6 & Analis & 2 \\
\hline 7 & Penyusun & 1 \\
\hline 8 & Pengelola & 8 \\
\hline 9 & Pengadministrasi & 8 \\
\hline 10 & Operator & 12 \\
\hline 11 & Adminstrasi Kantor & 11 \\
\hline \multirow[t]{2}{*}{12} & Petugas Kantor & 6 \\
\hline & Jumlah & 66 \\
\hline
\end{tabular}

Sumber: Badan Pengelola Keuangan Dan Aset Daerah Kabupaten Batu Bara -2021

\subsection{Sampel}

Sampel merupakan bagian dari elemenelemen populasi yang hendak diteliti. Adapun ide dasar dari pengambilan sampel adalah bahwa dengan menyeleksi bagian dari elelmenelemen populasi, kesimpulan tentang keseluruhan populasi diharapkan dapat diperoleh, Cooper \& Pamela (2011 : 95). Keunggulan ekonomis pengambilan sampel adalah biayanya lebih murah dan memberikan hasil yang lebih cepat. Dengan teknik penarikan sampel secara Total Sampling maka sampel dalam penelitian ini adalah seluruh populasi yaitu pegawai Badan Pengelola Keuangan Dan Aset Daerah Kabupaten Batu Bara sebanyak 65 orang. Karena peneliti sebagai Ka.Sub Bid Pemeriksaan tidak ikut dalam penelitian ini.

\subsection{Uji Validitas Data}

Suatu instrumen yang valid atau sahih mempunyai validitas yang tinggi. Sebaliknya instrumen yang kurang valid berarti memiliki validitas rendah (Arikunto, 2014:160). Sebelum dilakukan pengumpulan data, pertanyaan di dalam kuesioner diuji terlebih dahulu untuk mengetahui validitas dan reliabilitasnya. Cara pengukurannya menggunakan SPSS Versi 24.00, untuk mengetahui setiap butir pernyataan valid atau tidak valid yaitu dengan syarat:

a. Jika $r$ hitung $\geq \mathrm{r}$ tabel dengan signifikasi 95\%, maka instrumen tersebut dinyatakan valid.

b. Jika $\mathrm{r}$ hitung $\leq \mathrm{r}$ tabel dengan signifikasi 95\%, maka instrumen tersebut dinyatakan tidak valid (Sugiyono, 2015:213).

Nilai $\mathrm{r}$ hitung untuk pengujian ini dapat diketahui melalui hasil pengolahan data melalui SPSS versi 24.00 ( lihat lampiran). Sedangkan nilai $r$ tabel untuk $n=65$ dan taraf kesalahan $(\alpha) 0,05 \%$ adalah sebesar 0,244 (db $=\mathrm{n}-2)$. Dari proses uji validitas yang dilakukan terhadap 65 responden tersebut, maka hasil yang diringkas dapat ditunjukkan pada tabel berikut:

Table 2. Hasil Uji Validitas Variabel (X1)

\begin{tabular}{|c|c|c|l|}
\hline Nomor Soal & \multicolumn{1}{|l|}{ rhitung } & \multicolumn{1}{|l|}{ rtabel } & Valid \\
\hline 1 & 0,451 & 0,244 & Valid \\
\hline 2 & 0,455 & 0,244 & Valid \\
\hline 3 & 0,715 & 0,244 & Valid \\
\hline 4 & 0,715 & 0,244 & Valid \\
\hline 5 & 0,618 & 0,244 & \\
\hline
\end{tabular}




\begin{tabular}{|c|c|c|c|}
\hline Nomor Soal & rhitung & \multicolumn{1}{|l|}{ rtabel } & Veterangan \\
\hline 6 & 0,451 & 0,244 & Valid \\
\hline 7 & 0,684 & 0,244 & Valid \\
\hline 8 & 0,715 & 0,244 & Valid \\
\hline 9 & 0,523 & 0,244 & Valid \\
\hline 10 & 0,455 & 0,244 & \\
\hline
\end{tabular}

Table 3. Hasil Uji Validitas Variabel (X2)

\begin{tabular}{|c|c|c|c|}
\hline Nomor Soal & rhitung & rtabel & Keterangan \\
\hline 1 & 0,358 & 0,244 & Valid \\
\hline 2 & 0,460 & 0,244 & Valid \\
\hline 3 & 0,745 & 0,244 & Valid \\
\hline 4 & 0,745 & 0,244 & Valid \\
\hline 5 & 0,609 & 0,244 & Valid \\
\hline 6 & 0,358 & 0,244 & Valid \\
\hline 7 & 0,578 & 0,244 & Valid \\
\hline 8 & 0,745 & 0,244 & Valid \\
\hline 9 & 0,554 & 0,244 & Valid \\
\hline 10 & 0,460 & 0,244 & Valid \\
\hline
\end{tabular}

Table 4. Hasil Uji Validitas Variabel (X3)

\begin{tabular}{|c|c|c|c|}
\hline Nomor Soal & rhitung & rtabel & Keterangan \\
\hline 1 & 0,337 & 0,244 & Valid \\
\hline 2 & 0,397 & 0,244 & Valid \\
\hline 3 & 0,784 & 0,244 & Valid \\
\hline 4 & 0,784 & 0,244 & Valid \\
\hline 5 & 0,631 & 0,244 & Valid \\
\hline 6 & 0,337 & 0,244 & Valid \\
\hline 7 & 0,520 & 0,244 & Valid \\
\hline 8 & 0,784 & 0,244 & Valid \\
\hline 9 & 0,487 & 0,244 & Valid \\
\hline 10 & 0,397 & 0,244 & Valid \\
\hline
\end{tabular}

Table 5. Hasil Uji Validitas Variabel (Y)

\begin{tabular}{|c|c|c|c|}
\hline Nomor Soal & rhitung & rtabel & Keterangan \\
\hline 1 & 0,429 & 0,244 & Valid \\
\hline 2 & 0,427 & 0,244 & Valid \\
\hline 3 & 0,755 & 0,244 & Valid \\
\hline 4 & 0,755 & 0,244 & Valid \\
\hline 5 & 0,594 & 0,244 & Valid \\
\hline 6 & 0,429 & 0,244 & Valid \\
\hline 7 & 0,664 & 0,244 & Valid \\
\hline 8 & 0,755 & 0,244 & Valid \\
\hline 9 & 0,534 & 0,244 & Valid \\
\hline 10 & 0,427 & 0,244 & Valid \\
\hline
\end{tabular}

Sumber: Out Put SPSS Data Diolah-2021

Berdasarkan tabel 2 hingga tabel 5 correlation (rhitung) lebih besar dari rtabel dan sebahagian seluruh pernyataan dalam setiap dinyatakan valid. Apabila di temukan variabel memiliki nilai coreccted item 
pernyataan yang tidak valid tidak akan dilanjutkan ke pengujian reliabilitas.

\subsection{Uji Reliabilitas Data}

Reliablitas artinya memiliki sifat dapat dipercaya. Suatu alat ukur dapat dikatakan memiliki reliabilitas apabila digunakan berkalikali oleh peneliti yang sama atau peneliti lain tetap memberikan hasil yang sama (Rakhmat, 2011:17). Uji reliabilitas dengan menggunakan SPSS Versi 24.00 yang akan dilakukan menggunakan Reliability Analysis Statistic dengan Cronbach Alpha $(\alpha)$. Jika nilai Cronbach Alpha $(\alpha)>0,60$, maka dapat dikatakan variabel tersebut reliabel. Hasil uji reliabilitas penelitian ini adalah sebagai berikut:

Table 6. Hasil Uji Reliabilitas

\begin{tabular}{|l|r|r|l|}
\hline Variable & $\begin{array}{l}\text { Cronbach's } \\
\text { Alpha }\end{array}$ & $\begin{array}{l}\text { N of } \\
\text { Items }\end{array}$ & $\begin{array}{l}\text { Reabilitas } \\
\text { Status }\end{array}$ \\
\hline $\mathrm{X} 1$ & 0,809 & 10 & Reliabel \\
\hline $\mathrm{X} 2$ & 0,795 & 10 & Reliabel \\
\hline $\mathrm{X} 3$ & 0,770 & 10 & Reliabel \\
\hline $\mathrm{Y}$ & 0,810 & 10 & Reliabel \\
\hline
\end{tabular}

Sumber: Out Put SPSS Data Diolah-2021

Dengan membandingkan hasil perhitungan yang diperoleh dengan menggunakan Cronbach Alpha, masing-masing indikator dengan standar alpha yakni 0,6, maka diketahui bahwa masingmasing indikator memiliki nilai alpha yang $(>)$ lebih besar dari 0,6. Berdasarkan hasil tersebut maka dapat disimpulkan bahwa semua indicator dari variabel yang digunakan dalam penelitian dinyatakan reliabel atau andal.

\subsection{Uji Asumsi Klasik}

\subsubsection{Uji Normalitas Data}

Pengujian normalitas data bertujuan untuk melihat normal tidaknya sebaran data yang akan dianalisis. Untuk melihat normalitas data ini digunakan pendekatan grafik yaitu Normality Probability Plot.

Deteksi normalitas dengan melihat penyebaran data (titik) pada sumbu diagonal dari grafik. Menurut Santoso (2014:214), dasar pengambilan keputusan adalah:

a. Jika data menyebar disekitar garis diagonal dan mengikuti arah garis diagonal, maka model regresi memenuhi asumsi normalitas.

b. Jika data menyebar jauh dari garis diagonal dan atau tidak mengikuti arah garis diagonal, maka model regresi tidak memenuhi asumsi normalitas. Pada output SPSS versi 24.00 bagian normal $P$-P Plot of Regresion Standardized Residual, dapat dijelaskan bahwa data-data (titik-titik) cenderung lurus mengikuti garis diagonal sehingga data dalam penelitian ini cenderung berdistribusi normal, seperti terlihat pada gambar dibawah ini.

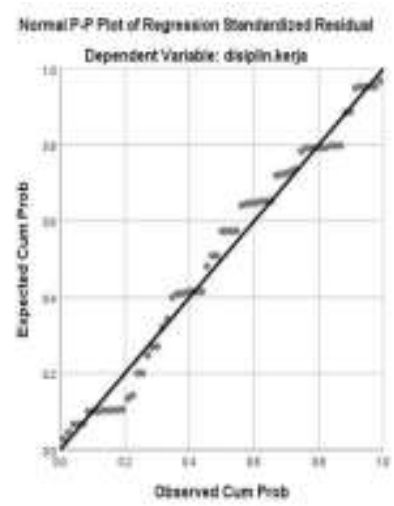

Gambar 1. Normalitas Data Sumber: Out Put SPSS Data Diolah-2021

\subsubsection{Uji Multikolinearitas}

Pengujian multikolinearitas dilakukan untuk melihat apakah pada model regresi ditemukan adanya korelasi antara variabel bebas. Jika terjadi korelasi, maka dinamakan terdapat problem multikolinearitas. Cara mendeteksinya adalah dengan melihat nilai Variance Inflation Factor (VIF). Menurut Santoso (2014:203), pada umumnya jika VIF lebih besar dari 5, maka variabel bebas tersebut mempunyai persoalan multikolinearitas dengan variabel bebas lainnya.

Pada ouput SPSS bagian Coefficient, semua angka VIF berada dibawah 5, hal ini menunjukan tidak terjadi multikolinearitas, seperti dapat dilihat pada tabel dibawah ini.

Table 6. Hasil Uji Multikolinearitas

\begin{tabular}{|l|l|r|r|}
\hline \multicolumn{2}{|l|}{ Model } & \multicolumn{2}{c|}{ Collinearity Statistics } \\
\cline { 3 - 4 } \multicolumn{2}{l|}{1} & Tolerance & \multicolumn{1}{c|}{ VIF } \\
\cline { 2 - 4 } & Constant) & & \\
\cline { 2 - 4 } & kemandirian.pribadi & .800 & 1.251 \\
\cline { 2 - 4 } & budaya.organisasi & .792 & 1.263 \\
\cline { 2 - 4 } & pengawasan & .699 & 1.431 \\
\hline
\end{tabular}

a. Dependent Variable: disiplin.kerja

Sumber: Out Put SPSS Data Diolah-2021

\subsubsection{Uji Heteroskedastisitas}

Pengujian heteroskedastisitas bertujuan untuk melihat apakah dalam sebuah model regresi terjadi ketidaksamaan varians dari 
residual yang merupakan suatu pengamatan ke pengamatan yang lainnya. Jika varians dari residual yang merupakan suatu pengamatan ke pengamatan yang lain bernilai tetap, maka hasil data disebut homoskedastisitas dan jika varians berbeda atau bernilai tidak tetap maka disebut heteroskedastisitas. Model regresi yang baik adalah model yang bernilai tetap atau homoskedastisitas atau tidak terjadi heteroskedastisitas.

Deteksi heteroskedastisitas dilakukan dengan cara melihat ada tidaknya pola tertentu pada data yang diolah. Menurut Santoso (2014:208), dasar pengambilan keputusannya adalah:

a. Jika pola tertentu seperti titik-titik yang ada membentuk suatu pola tertentu yang teratur, maka terdapat situasi heteroskedastisitas.

b. Jika tidak ada pola yang jelas, serta titik-titik menyebar diatas dan dibawah angka nol pada sumbu Y, maka tidak terjadi heteroskedastisitas.

Pada output SPSS dibagian Scatrerplot, terlihat titk-titik menyebar secara acak, tidak membentuk sebuah pola tertentu yang jelas, serta tersebar baik diatas maupun dibawah angka nol pada sumbu Y. Hal ini berarti tidak terjadi heterskedastisitas pada model regresi, sehingga model regresi layak dipakai. Pola

Scatterplot dapat dilihat pada gambar dibawah ini.

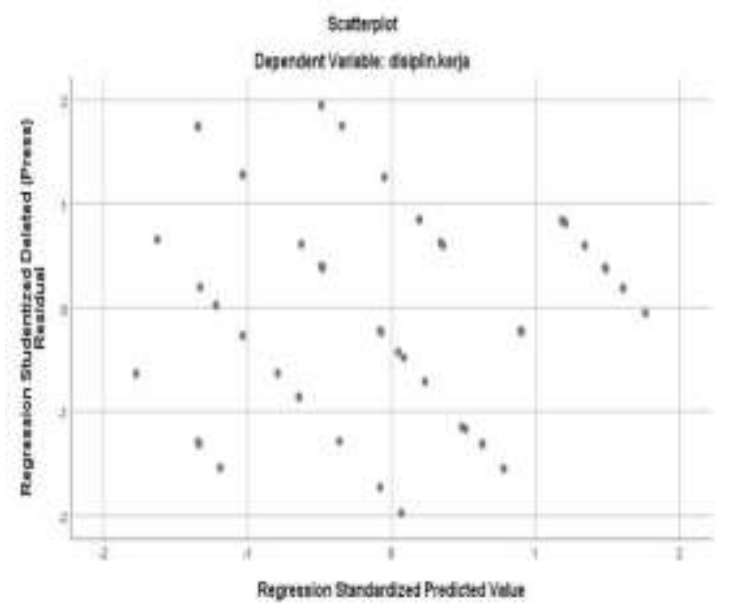

Gambar 2. Uji Heteroskedastitas

\section{Evaluasi Data (Analisa Regresi Linier Berganda )}

\subsection{Pengujian Hipotesis}

Dalam evaluasi data ini penulis akan melakukan pengujian hipotesis, baik secara partial ataupun secara simultan. Selanjutnya untuk mempermudah dalam evaluasi data ini, maka penulis mencari niali-nilai yang dibutuhkan dengan menggunakan perangkat lunak komputer yaitu program SPSS V.24.00 for windows dengan hasil data sebagai berikut:

Tabel 7. Hasil Uji Statistik Keofesien Regresi

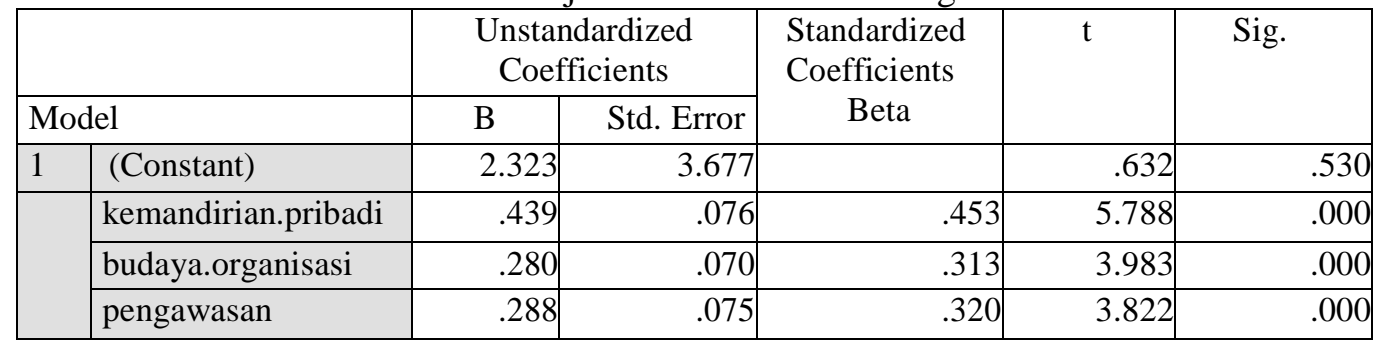

a. Dependent Variable: disiplin.kerja

Sumber: Out Put SPSS Data Diolah-2021

Berdasarkan tabel 5.12 diatas dapat dibuat persamaan regresi sebagai berikut:

$Y=2,323+0,439 X 1+0,280 X 2+0,288 X 3+\varepsilon$

Persamaan diatas dijelaskan bahwa koefesien kemandirian pribadi mempunyai nilai positif yaitu 0,439 , hal ini menunujukan bahwa variabel kemandirian pribadi mempunyai pengaruh positif terhadap disiplin kerja.

Berdasarkan persamaan diatas bahwa koefesien budaya organisasi memiliki nilai positif yaitu 0,280 . Hal ini menunjukan bahwa variabel budaya organisasi mempunyai pengaruh positif terhadap disiplin kerja.
Berdasarkan persamaan diatas bahwa koefesien pengawasan memiliki nilai positif yaitu 0,288 . Hal ini menunjukan bahwa variabel pengawasan juga mempunyai pengaruh positif terhadap disiplin kerja.

\subsection{Pengujian Secara Simultan (Uji F)}

Untuk melihat hasil seberapa besar pengaruh yang di berikan variabel independen terhadap dependen secara simultan ( bersama-sama) pada penelitian ini maka dapat di jelaskan pada tabel di bawah ini : 
Tabel 8 Hasil Uji Statistik Secara Simultan

\begin{tabular}{|l|l|r|r|r|r|r|}
\hline Model & & Sum of Squares & df & Mean Square & F & Sig. \\
\hline \multirow{2}{*}{1} & Regression & 67.031 & 3 & 22.344 & 47.811 & $.000^{\mathrm{b}}$ \\
\hline \multirow{2}{*}{} & Residual & 28.507 & 61 & .467 & & \\
\cline { 2 - 8 } & Total & 95.538 & 64 & & & \\
\hline
\end{tabular}

a. Dependent Variable: disiplin. kerja

b. Predictors: (Constant), pengawasan, kemandirian.pribadi, budaya.organisasi

Pada tabel 8 diatas terlihat bahwa nilai Fhitung adalah 47,811 dan nilai signifikansi 0,000. Diketahui nilai Ftabel dengan tingkat kepercayaan $95 \%(\alpha: 0,05)$ adalah 2,740 . Oleh karena itu nilai Fhitung > Ftabel ( 47,811 $>$ 2,740 ) maka Ho ditolak dan menerima hipotesis dalam penelitian ini bahwa kemandirian pribadi, budaya organisasi dan pengawasan secara simultan berpengaruh positif dan signifikan terhadap disiplin kerja pegawai Badan Pengelola Keuangan Dan Aset Daerah Kabupaten Batu Bara.

\subsubsection{Pengujian Secara Parsial (Uji t)}

Tabel 9. Hasil Uji Parsial Variabel X Terhadap Y

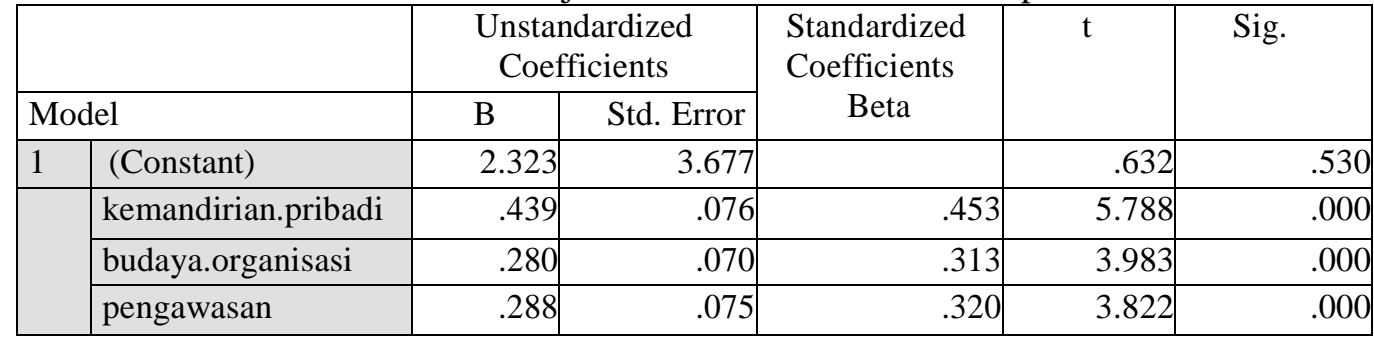

a. Dependent Variable: disiplin.kerja

Sumber: Out Put SPSS Data Diolah-2021

\subsubsection{Pengaruh Kemandirian Pribadi Terhadap Disiplin Kerja}

Untuk mengetahui secara parsial pengaruh kemandirian pribadi terhadap disiplin kerja pegawai dapat dilihat pada tebel 5.14 diatas. Berdasarkan tabel tersebut diperoleh nilai thitung sebesar 5,788 dan nilai signifikansi $\quad 0,000$. Sedangkan nilai ttabel pada tingkat kepercayaan 95\% ( $\alpha: 0,05)$ adalah 2,000 . Oleh karena itu nilai thitung $>$ tabel $(5,788>2,000)$ maka $\mathrm{H}_{\mathrm{o}}$ ditolak dan menerima hipotesis dalam penelitian ini bahwa kemandirian pribadi secara parsial berpengaruh positif terhadap disiplin kerja pegawai Badan Pengelola Keuangan Dan Aset Daerah Kabupaten Batu Bara.

\subsubsection{Pengaruh Budaya Organisasi Terhadap Disiplin Kerja}

Untuk mengetahui secara parsial pengaruh budaya organisasi terhadap disiplin kerja pegawai, dapat dilihat pada tebel 5.14 diatas. Berdasarkan tabel tersebut diperoleh nilai thitung sebesar 3,983 dan nilai signifikansi 0,000 . Sedangkan nilai ttabel pada tingkat kepercayaan $95 \%(\alpha: 0,05)$ adalah
2,000. Oleh karena itu nilai thitung > ttabel ( $3,983>2,000$ ) maka Ho ditolak dan menerima hipotesis dalam penelitian ini bahwa budaya organisasi secara parsial berpengaruh positif terhadap disiplin kerja pegawai Badan Pengelola Keuangan Dan Aset Daerah Kabupaten Batu Bara.

\subsubsection{Pengaruh Pengawasan Terhadap Disiplin Kerja}

Untuk mengetahui secara parsial pengaruh pengawasan terhadap disiplin kerja pegawai, dapat dilihat pada tebel 5.14 diatas. Berdasarkan tabel tersebut diperoleh nilai thitung sebesar 3,822 dan nilai signifikansi 0,000 . Sedangkan nilai ttabel pada tingkat kepercayaan 95\% ( $\alpha: 0,05)$ adalah 2,000. Oleh karena itu nilai thitung > ttabel (3,822 > 2,000) maka $\mathrm{H}_{\mathrm{O}}$ ditolak dan menerima hipotesis dalam penelitian ini bahwa pengawasan secara parsial berpengaruh positif terhadap disiplin kerja pegawai Badan Pengelola Keuangan Dan Aset Daerah Kabupaten Batu Bara. 


\subsubsection{Uji Koefisien Determinasi $\left(\mathbf{R}^{\mathbf{2}}\right)$}

Uji determinan adalah uji yang dilakukan untuk mengetahui seberapa besar pengaruh variabel independent (kemandirian pribadi, budaya organisasi dan pengawasan) terhadap

Tabel 10. Model Summary

\begin{tabular}{|c|c|c|c|c|c|c|}
\hline \multirow[t]{2}{*}{ Model } & & \multirow[t]{2}{*}{ R Square } & \multirow{2}{*}{$\begin{array}{l}\text { Adjusted R } \\
\text { Square }\end{array}$} & \multirow{2}{*}{$\begin{array}{c}\text { Std. Error of the } \\
\text { Estimate }\end{array}$} & \multicolumn{2}{|c|}{ Change Statistics } \\
\hline & & & & & $\begin{array}{c}\text { R Square } \\
\text { Change }\end{array}$ & F Change \\
\hline 1 & $.838^{a}$ & .702 & .687 & .68362 & .702 & 47.811 \\
\hline
\end{tabular}

a. Predictors: (Constant), pengawasan, kemandirian.pribadi, budaya.organisasi

b. Dependent Variable: disiplin.kerja

Nilai R Square pada tabel 10. diatas adalah 0,702. Hal ini menunjukan bahwa $70,20 \%$ variabel disiplin kerja pegawai Badan Pengelola Keuangan Dan Aset Daerah Kabupaten Batu Bara dapat di jelaskan oleh variabel kemandirian pribadi, budaya organisasi dan pengawasan sedangkan sisanya sebesar $29,80 \%$ di dijelaskan oleh variabel lain yang tidak di teliti.

\section{Kesimpulan}

a. Kemandirian pribadi secara parsial berpengaruh positif terhadap disiplin kerja pegawai Badan Pengelola Keuangan Dan Aset Daerah Kabupaten Batu Bara

b. Budaya organisasi secara parsial berpengaruh positif terhadap disiplin kerja pegawai Badan Pengelola Keuangan Dan Aset Daerah Kabupaten Batu Bara

c. Pengawasan secara parsial berpengaruh positif terhadap disiplin kerja pegawai Badan Pengelola Keuangan Dan Aset Daerah Kabupaten Batu Bara

d. Kemandirian pribadi, budaya organisasi dan pengawasan secara simultan berpengaruh positif dan signifikan terhadap disiplin kerja pegawai Badan Pengelola Keuangan Dan Aset Daerah Kabupaten Batu Bara

e. Nilai R Square adalah 0,702. Hal ini menunjukan bahwa 70,20\% variabel disiplin kerja pegawai Badan Pengelola Keuangan Dan Aset Daerah Kabupaten Batu Bara dapat di jelaskan oleh variabel kemandirian pribadi, budaya organisasi dan pengawasan sedangkan sisanya sebesar $29,80 \%$ di dijelaskan oleh variabel lain yang tidak di teliti

\section{DAFTAR PUSTAKA}

Ali, Cahyono. 2010. Analisa Pengaruh Kepemimpinan, Motivasi Dan Budaya variabel dependent (disiplin kerja). Untuk melihat hasil uji determinan maka dapat diketahui nili $\mathrm{R}$ Square atau koefesien determinasi dan dapat dilihat dibawah ini.

\section{Organisasi Terhadap Kinerja Dosen Dan Pegawai Di Universitas Pawyatan Daha} Kediri. Jurnal Ilmu Manajemen, Revitalisasi, Vol. 1, No.

Asmirasih, Tety. 2016. Pengaruh Pengawasan Terhadap Disiplin Kerja Pada Kantor Badan Kepegawaian Daerah Kabupaten Brebes. Skripsi Fakultas Ekonomi Universitas Semarang

Azwar, S. 2017. Metode Penilitan. Yogyakarta: Pustaka Pelajar.

Budinurani, Anie. 2012. Kemandirian Pada Remaja Putra Yang Menikah

Muda. Jakarta: Raja Grafindo Parsada.

Chatab, Nevizond. 2012. Profil Budaya Organisasi. Bandung: Penerbit Alfabeta. Cooper, Donald R and Pamela S. Schlindler. 2011. Metode Riset Bisnis, Volume 1 Edisi Sembilan, Alih Bahasa Budijanto dkk. McGraw-Hill Irwin. Jakarta.

Desmita. 2012. Psikologi Perkembangan Peserta Didik. Bandung: Remaja Rosdakarya.

Dharma, Surya. 2010. Manajemen Kinerja Falsafah Teori dan Penerapannya. Yogyakarta: Pustaka Pelajar.

Effendy, Usman. 2013. Asas - Asas Manajemen, cetakan Ke II. Jakarta: Rajawali Pers.

Ernie, Tisnawati Sule. 2015. Pengantar Manajemen. Depok: Prenadamedia Group.

Fattah, Nanang. 2014. Landasan Manajemen Pendidikan. Bandung: Remaja Rosdakarya.

Hasibuan, Malayu S.P. 2011. Organisasi dan Motivasi. Jakarta: Bumi Akasara. Hesselbein, Goldsmith, Beckhard. 2013. The Organization of the Future. San Fransisco : Jossey Bush Publishers.

Hofstede, G. J. 2010. Measuring Organizational Cultures: A Qualitative 
and Quantitative Study Across Twenty Cases. New York: Administrative Science Quarterly.

Kadarisman, M. 2012. Manajemen kompensasi. Jakarta: Rajawali pers.

Kansil, C.S.T. 2012. Pokok-Pokok hukum kepegawaian Republik Indonesia. Jakarta: Pradnya Paramitha.

Kartono, Kartini, 2012. Pemimpin dan Kepemimpinan: Apakah Pemimpin Abnormal Itu? Jakarta: RajaGrafindo Persada.

Mangkunegara, A.P. 2012. Evaluasi Kinerja Sumber Daya Manusia. Bandung: Remaja Rosdakarya.

Nicholson, Walter dan John J Wild. 2010. Teori Ekonomi Mikro Prinsip Dasar dan Pengembangannya. Jakarta: PT Raja Grafindo Persada.

Octavianthi. 2011. Perjuangan Semesta Melawan Korupsi.http://octaoctavianthi.blogspot.com

Pasaribu, Afrizal. 2011. Metode Penelitian Kualitatif. Jakarta: Graha Ilmu. Riva'i, Veithzal. 2011. Kepemimpinan dan Perilaku Organisasi. Jakarta: PT.

Raja Grafindo Persada.

Robbins, Stephen P. 2012. Perilaku Organisasi. Jakarta: Salemba Empat. Safrudin, Alwi 2012. Manajemen Sumber Daya Manusia. Yogyakarta: BPFE. Siagian, Sondang P. 2010. Administrasi Pembangunan Konsep, Dimensi Dan Strateginya. Jakarta: CV Haji Mas Agung. 2013.

Filsafat

Administrasi. Jakarta: Gunung agung.

2014.

Manajemen Sumber Daya Manusia. Jakarta: Gunung agung.

2015. Sistem

Informasi Manajemen. Jakarta: Gunung agung.

Simamora, Henry. 2012. Manajemen Personalia. Yogyakarta: STIE YKPN Yogyakarta.

Singarimbun, M dan Efendi. 2012. Metode Penelitian Survey. Jakarta: PT. Pustaka LP3ES.

Sinungan, Muchdarsyah. 2015. Produktivitas Apa dan Bagaimana. Jakarta: Bumi Aksara.

Siswanto, Bejo. 2013. Manajemen Tenaga Kerja Indonesia, Pendekatan Administratif dan Operasional. Jakarta: Bumi Aksara.
Situmorang \& Juhir. 2011. Manajemen Sumber Daya Manusia. Bandung: Pustaka Setia.

Sudirman, P. 2015. Interaksi \& Motivasi Belajar Mengajar. Jakarta: PT. Raja Grafindo Persada

Sumodiningrat. 2011. Pengantar Statistika. Jakarta: Andi.

Suniastuti, Ni Putu ester dan I Wayan Suana. 2011. Pengaruh Karakteristik Individu,

Budaya Organisasi Dan Komunikasi Terhadap Disiplin Kerja Pegawai Perusahaan Daerah Parkir Kota Denpasar. Jurnal.

Trenggono. 2018. Metode Penelitian Manajemen. Jakarta: Rajawali Pers.

Ukas, Maman. 2014. Manajemen: Konsep, Prinsip dan Aplikasi. Bandung: Agnini.

Umar, Husein. 2013. Riset Sumber Daya Manusia. Jakarta: Gramedia. Wibowo. 2011. Budaya Organisasi. Jakarta: PT. Raja Grafindo Persada. Wirawan. 2010. Evaluasi Kinerja Sumber Daya Manusia. Jakarta. Penerbit: Salemba Empat.

2014. Manajemen Sumber Daya Manusia Indonesia. Jakarta. Penerbit: Salemba Empat.

Wursanto. 2017. Dasar-Dasar Ilmu Organisasi. Yogyakarta: Andi.

Yulia, Riawan. 2016. Perbedaan Kemandirian Remaja Ditinjau Dari Data Demografi (Urutan Kelahiran Dan Jenis Kelamin).Tesis Pekanbaru: UIN Sultan Syarif Kasim. 